while I was on stiand near a game reserve I had two deer walk within three feet of me and one of them I could have poked in the ribs with the gun barrel. And I had a cow moose walk to within twenty yards of me. look me over and then walk away into the bush! It is a caution how close animals will come to you if you stand very still near a tree or bush and remain absolutely motionless while they are in sight.

The list and greatest disappointment occurred while I was trying to get my elk. A hunter came into the district in a large truck with a pony in the back and a toboggan to which he intended to hitch the pony. $\mathrm{He}$ put a red blanket on the pony and also a set of bells, and he and his pard drove all through the timber for miles in that district riding the toboggan looking for elk. He would follow a bunch of elk tracks and chase the elk right out of the district, doing this day after day till the end of the season. The only thing he saw was a lot of elk tracks, and the elk sure made a lot of them for him! He never got within miles of the elk with that silly outfit he had; all he did was spoil the hunting for about a dozen other hunters. You can see the reason why this was one season I myself did not get my elk.

EDITOR'S NOTE: In response to frequent appeals in the past for contributions from hunters and members of the province's fish and game leagues, we have this delightful account of Mr. Morgan's hunting experiences. We teel that the hunter who takes a legitimate harvest cf game within the legal limits of an intelligently planned game management programme plays an important role in the utilization of our natural resources.

\title{
New Elk Display at Museum
}

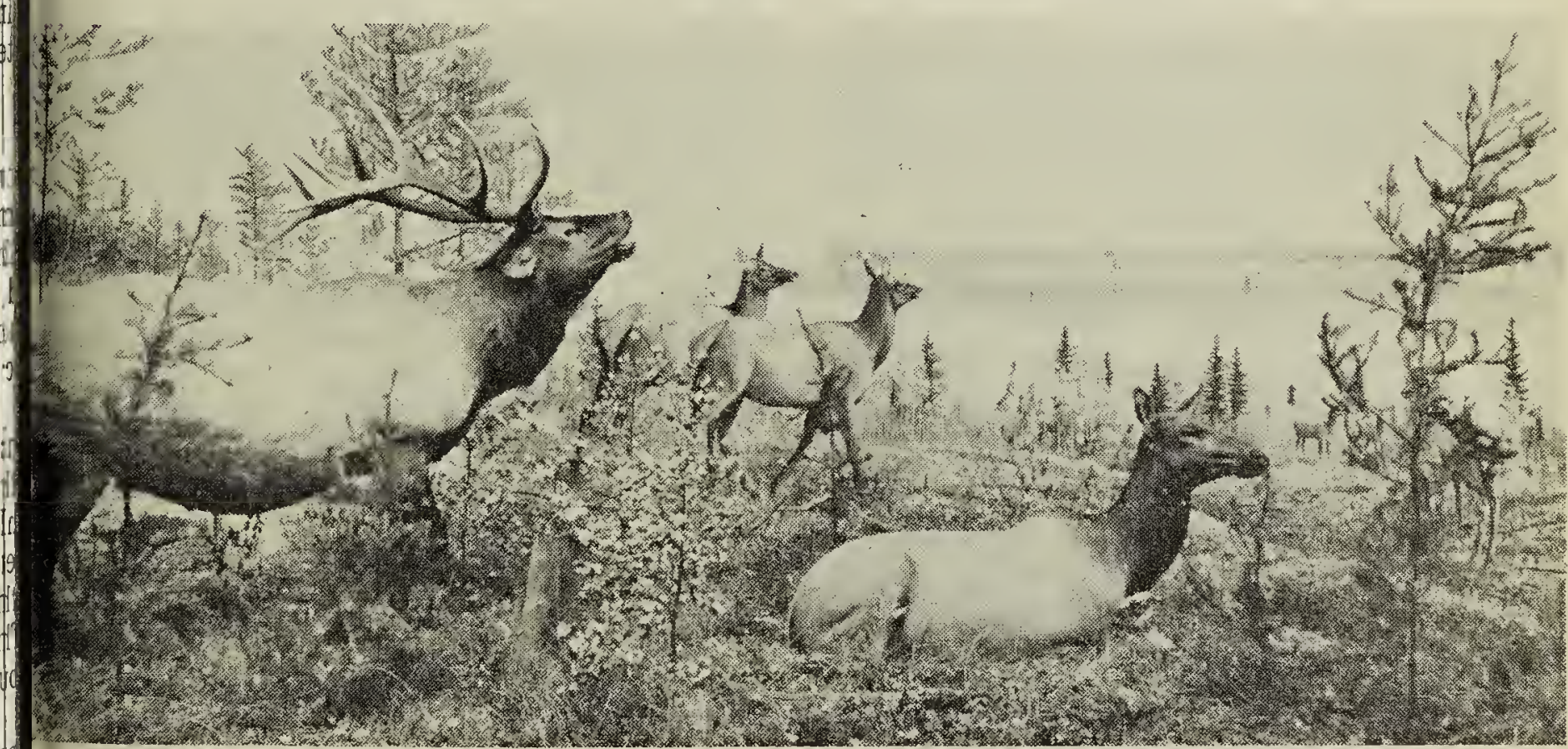

Sask. Govt. Photo

The above photograph shows the recently completed elk display at the Saskatchewan Museum of Natural History. The elk display was officially opened by Fred Bard, Director of the Museum, at an interesting ceremony held January 20 in conjunction with the regular monthly meeting of the Regina Natural History Society.

The habitat displays in the new museum have been planned to represent the variety of environments and wildlife characteristic of the province of Saskatchewan, Mr. Bard said in opening the new display. The display of North American elk or wapiti in a natural setting-along the north bank of the Saskatchewan River east of the Fort à la Corne Provincial Forest-completes the series of 24 habitat groups.

The elk display shows a bull elk and his harem. The season is midSeptember and the elk is at his prime; his antlers are fully grown and his bugling challenge rings across the river. A commanding ridge, such as the one seen here, serves as an excellent vantage point from which the 
bull can challenge all comers. Before the season is over a single bull may collect as many as 40 cows in his harem.

A colour film on North American elk (made in Wyoming) shown at the opening ceremony followed the elk through the seasons. The calves are born in May or June and remain with the cows throughout the summer. By October they are weaned and able to forage for themselves, though they may remain with the cows for another six months. Young bull elk develop antlers the first year, and these are shed each spring.

The name "elk" was given this animal by early settlers who thought it similar to European elk. The Shawnee Indians called the elk "wapiti" and this name is still preferred by many naturalists. The North American elk belongs to the same genus as the European red deer, and its true place in the animal kingdom is indicated by its scientific name Cervus canadensis.

Elk may be found in several areas of Saskatchewan - along the North Saskatchewan River in the locality depicted in the museum display, at
Greenwater Lake, Moose Mountair Cypress Hills, Meadow Lake, an Prince Albert National Park. It numbers are not great, but it he been saved from becoming extin through game management pro grammes in Saskatchewan and othe provinces.

The bull elk in the museum dis play was taken at English Creek late November a few years ago by party consisting of C. McLean, Bunting and F. Bard. Mr. Bard re calls that in $-26^{\circ}$ weather a sno drift remained in the room of tr shack in which they were campin for the four days of their stay ther The elk was shot on the bank of th creek, and had to be "packed out" o the men's backs to the camp site. Th cow elk was collected in October 1956 by a party consisting of $\mathrm{F}$. Lah man, B. McCorquodale, A Swansto. and $W$. Niessen.

Many tasks are involved in th preparation of a habitat group, fro: the time the specimens are collecte until the glass front is put in plac The preparation of a habitat group a good example, said Mr. Bard, teamwork among the members of th museum staff.

\section{INFORMATION WANTED}

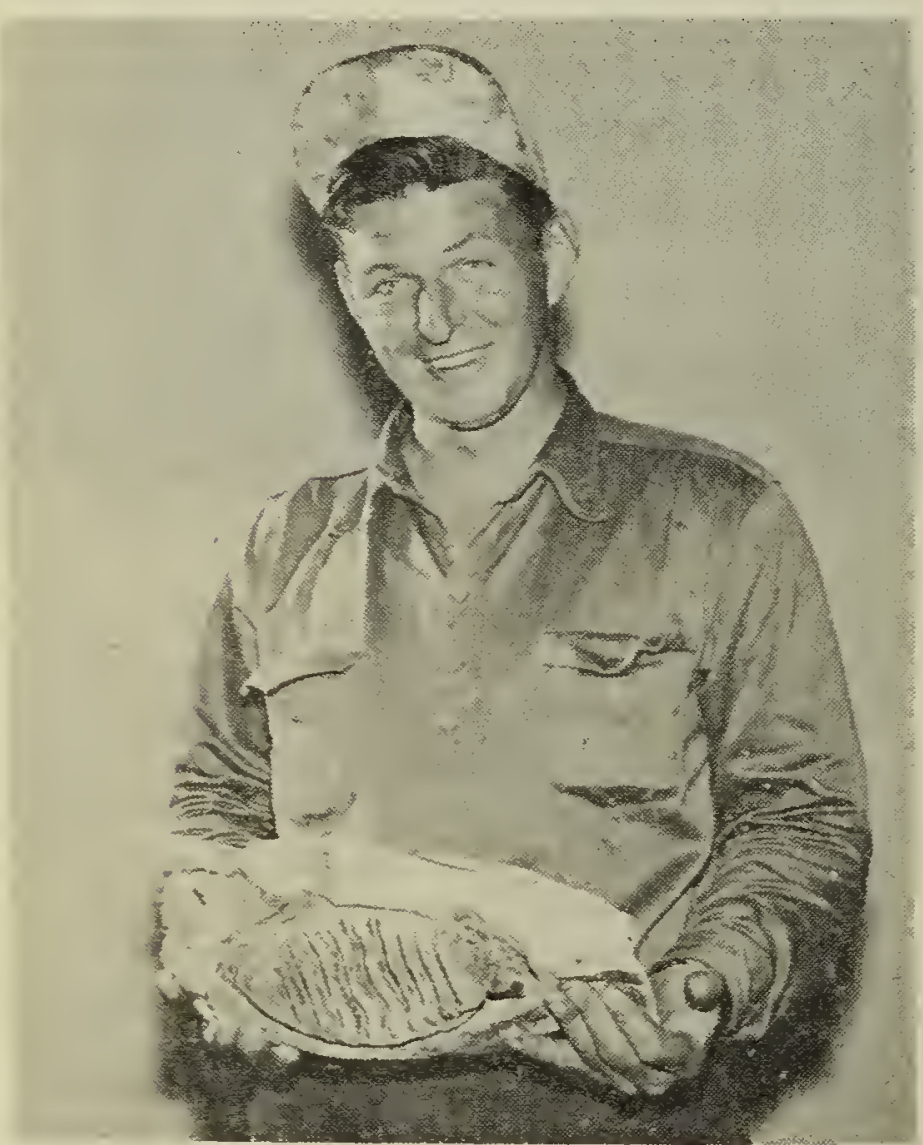

Sask. Govt. Photo by L. Robinson

Cliff Paul holding the jaw bone and molar found in gravel pit near Pilot Butte.
The above photograph indicates tt size and general appearance of mola from "Mammoths" or ice-age el phants which roamed Saskatchewe throughout the major part of the la million years. These molars have laminated appearance due to the structure of alternating plates dentine and cement which tend separate upon fragmentation. Bru A. McCorquodale of the Saskatch wan Museum of Natural History undertaking a study of the distrib tion of this extinct genus. This stuc will be based chiefly upon records discoveries of bones or teeth of the mammals. Any reports receivi from readers or their friends on $t$. occurrence of mammoth teeth private collections would be great appreciated by Mr. McCorquoda 